\title{
Cover crops and herbicide timing management on soybean yield under no-tillage system
}

\author{
Adriano Stephan Nascente ${ }^{(1)}$ and Carlos Alexandre Costa Crusciol ${ }^{(2)}$
}

\begin{abstract}
(1)Embrapa Arroz e Feijão, Rodovia GO-462, Km 12, Zona Rural, Caixa Postal 179, CEP 75375-000 Santo Antônio de Goiás, GO, Brazil. E-mail: adriano@cnpaf.embrapa.br (2)Universidade Estadual Paulista, Faculdade de Ciências Agronômicas, Departamento de Produção Vegetal, Campus de Botucatu, Caixa Postal 237, CEP 18603-970 Botucatu, SP, Brazil. E-mail: crusciol@fca.unesp.br
\end{abstract}

\begin{abstract}
The objective of this work was to evaluate the effect of cover crops and timing of pre-emergence herbicide applications on soybean yield under no-tillage system. The experiment consisted of four cover crops (Panicum maximum, Urochloa ruziziensis, U. brizantha, and pearl millet) and fallow, in addition to four herbicide timings (30, 20, 10, and 0 days before soybean sowing), under no-tillage system (NTS), and of two control treatments under conventional tillage system (CTS). The experimental design was a completely randomized block, in a split-plot arrangement, with three replicates. Soybean under fallow, P. maximum, U. ruziziensis, U. brizantha, and pearl millet in the NTS and soybean under U. brizantha in the CTS did not differ significantly regarding yield. Soybean under fallow in the CTS significantly reduced yield when compared to the other treatments. The amount of straw on soil surface did not significantly affect soybean yield. Chemical management of P. maximum and $U$. brizantha near the soybean sowing date causes significant damage in soybean yield. However, herbicide timing in fallow, U. ruziziensis, and pearl millet does not affect soybean yield.
\end{abstract}

Index terms: Glycine max, Panicum maximum, brachiaria, chemical management, herbicide timing, pearl millet.

\section{Plantas de cobertura e manejo da época de aplicação de herbicida na produção de soja em sistema plantio direto}

\begin{abstract}
Resumo - O objetivo deste trabalho foi avaliar o efeito de plantas de cobertura e época de aplicação de herbicidas antes do semeio na produtividade da soja em plantio direto. O experimento consistiu em quatro plantas de cobertura (Panicum maximum, Urochloa ruziziensis, U. brizantha e milheto) e pousio, além de quatro épocas de aplicação de herbicidas (30, 20, 10 e 0 dias antes do semeio da soja), em sistema plantio direto (SPD), e em dois tratamentos controle em sistema convencional (SC). Utilizou-se o delineamento experimental de blocos ao acaso, com parcelas subdivididas e três repetições. Soja sobre pousio, P. maximum, U. ruziziensis, U. brizantha e milheto em SPD e soja sobre $U$. brizantha em SC não diferiram significativamente entre si quanto à produtividade. Soja sobre pousio em SC resultou em redução significativa na produtividade da soja, em comparação aos demais tratamentos. A quantidade de palha na superfície do solo não teve efeito significativo na produtividade da soja. $\mathrm{O}$ manejo químico de $P$. maximum e $U$. brizantha próximo à época de semeadura da soja causa dano significativo na produtividade da soja. Entretanto, a época de aplicação do herbicida após pousio, U. ruziziensis e milheto não afeta a produtividade da soja.
\end{abstract}

Termos para indexação: Glycine max, Panicum maximum, braquiaria, manejo químico, época aplicação de herbicida, milheto.

\section{Introduction}

Soybean [Glycine $\max$ (L.) Merr.] is largely planted in soil under no-tillage system (NTS), which is becoming an important soil management in Brazil. During the 2009/2010 harvest, no-tillage systems covered close to 25 million hectares of land area in the country (Companhia Nacional de Abastecimento, 2011). The lack of soil disturbance, use of crop rotation and the inclusion of cover crops in rotations are the major characteristics of the NTS (Dabney et al., 2001; Oliveira Junior et al., 2008; Yahuza, 2011). Currently, the use of forage species, such as Urochloa and Panicum, has attracted the interest of farmers and researchers due to the high quality and quantity of the straw produced (Crusciol et al., 2005; Torres et al., 2008; Nunes et al., 2009; Valle \& Pagliarini, 2009).

Good results in the implementation of the NTS also depend on the proper management of the cover crop and on the use of herbicides. The management of cover crops before planting is done with systemic herbicides, of which glyphosate is the most widely used (Oliveira Junior et al., 2008). Glyphosate is a 
broad spectrum, non-selective systemic herbicide, normally used for the control of annual and perennial weeds and cover crops (Galli \& Montezuma, 2005; Matallo et al., 2009). However, the effect of glyphosate on plant coverage is slow, taking a few days for those plants to die completely (Constantin \& Oliveira Junior, 2005). Therefore, when herbicides are applied on the same day as that of soybean sowing, cover crops are still alive and standing. Consequently, there is initial shading in soybean seedlings, which harms their initial development (Santos et al., 2007). There have been reports of effects, such as yellowing, shading, reduced development, and reduction in crop yield (Constantin \& Oliveira Júnior, 2005). According to Matallo et al. (2009), when glyphosate is applied near the crop sowing time, there may occur root exudation of herbicides from cover crops to soybean, especially if the roots from the cover crops treated with the herbicide are numerous and close to the roots of the crop.

Previous studies have shown that the best time to dry out weeds or cover crops is between 7 and 20 days before soybean sowing (Santos et al., 2007; Nunes et al., 2009; Monquero et al., 2010). However, there are few studies on the best time for drying out cover crops before soybean seeding (Monquero et al., 2010).

The correct management of cover crops with chemicals can provide higher nutrient availability due to subsequent degradation, greater persistence of straw on soil surface, and lower release of allelopathic substances to the soil (Yamada \& Castro, 2007). It is also important to determine which cover crops are the best to promote soybean productivity.

The objective of this work was to evaluate the effect of cover crops and timing of pre-emergence herbicide applications on soybean yield under NTS.

\section{Materials and Methods}

The experiment was carried out in Santo Antônio de Goiás, GO, Brazil (16 $27^{\circ} \mathrm{S}$ and $49^{\circ} 17^{\prime} \mathrm{W}$, at $823-\mathrm{m}$ altitude). The climate of the region is a tropical savanna, classified as Aw, according to Köppen, with two well-defined seasons. The soil is an Oxisol (Santos et al., 2006) with gently undulating topography and clayey texture (540 $\mathrm{g} \mathrm{kg}^{-1}$ of clay, $11 \mathrm{~g} \mathrm{~kg}^{-1}$ of silt, and $35 \mathrm{~g} \mathrm{~kg}^{-1}$ of sand). Soil analysis was performed at $0-5$, 5-10, and 10-20-cm depth, according to Claessen (1997) (Table 1).
The experiment was done in an area that had been cultivated under NTS for six years (2001/2002 to $2006 / 2007)$ in rotation with corn (2001, 2003, and 2005) and soybean $(2002,2004$, and 2006) in the summer and fallow in the winter. This experiment consisted of cover crops in the first summer (2007/2008) and soybean in the second one (2008/2009).

The experimental design was a randomized complete block, in a split-plot, with three replicates in a 5.0x4.0 factorial arrangement (cover crops, plots) $\mathrm{x}$ (desiccation times, split-plots) under NTS, with two control treatments in the CTS. The cover crops used were: fallow, Panicum maximum, Urochloa ruziziensis (Syn. Brachiaria ruziziensis), Urochloa brizantha cultivar Marandu (Syn. Brachiaria brizantha cultivar Marandu), and pearl millet (Pennisetum glaucum (L.) R.BR cultivar BN-2). Two additional treatments were included under the CTS: U. brizantha incorporated 30 days before soybean sowing and fallow, when weeds were incorporated 30 days before soybean seeding. Plot size was $6.0 \times 40 \mathrm{~m}$, and split-plot size was $6.0 \times 10 \mathrm{~m}$.

Tropical forages were planted intercropped with corn (cultivar BRS 1010), in 0.20-m rows, using a mechanical planter set to distribute $10 \mathrm{~kg} \mathrm{ha}^{-1}$ of seeds with at least $30 \%$ of varietal purity, mixed with $\mathrm{N}-\mathrm{P}_{2} \mathrm{O}_{5}-\mathrm{K}_{2} \mathrm{O}$ fertilizer (4-30-16, $\left.400 \mathrm{~kg} \mathrm{ha}^{-1}\right)$, according to the "Santa Fé" system (Kluthcouski et al., 2000), on 11/27/2007. Pearl millet was sowed after soybean (cultivar Emgopa 316 RR) on 3/14/2008, at a 0.20 -m row spacing. The cultural practices were conducted in accordance with Kluthcouski et al. (2000). Cover crops were desiccated at 30,20,10, and 0 days before soybean sowing. The drying was done by applying herbicide glyphosate at $1.8 \mathrm{~kg} \mathrm{ha}^{-1}$ of acid equivalent using boom sprayer with spray volume of $200 \mathrm{~L} \mathrm{ha}^{-1}$. Environmental conditions during pulverization were weak winds, temperature around $25^{\circ} \mathrm{C}$, and relative humidity around $80 \%$. This procedure was done after drying dew of cover crop leaves.

Soybean was sowed on $11 / 21 / 2008$, using the cultivar 316 Emgopa $R R$ in $0.45-\mathrm{m}$ rows with 20 viable seeds per meter. Furrow opening, fertilizer distribution, and soybean seeding were done with a planter tractor implement (model Personale DRILL-13, Semeato, Passo Fundo, RS, Brazil). A total of $80 \mathrm{~kg} \mathrm{ha}^{-1}$ of $\mathrm{P}_{2} \mathrm{O}_{5}$ and $\mathrm{K}_{2} \mathrm{O}$ was used, and cultural practices were performed in accordance with the recommendations for the culture (Tecnologias de produção de soja, 2006). 
Plant stands were measured seven days after soybean emergence in one linear meter on the soybean row in each split-plot. Cover crops were sampled from a $1.0 \times 1.0-\mathrm{m}$ area randomly selected and then sampled four times in each plot. The collected plant material was placed in paper bags, dried in a forced ventilation oven at $65^{\circ} \mathrm{C}$, and weighed. Dry matter was converted to kilograms per hectare.

Soybeans were harvested by hand in three $5.0-\mathrm{m}$ rows. Plants were threshed and grain dried until seed moisture content reached $13 \%$. Data of soybean plant stand, cover crop dry matter, and soybean yield were subjected to analysis of variance in a randomized complete block design with three replicates using the SAS program (SAS Institute, 1999), and means were compared by the LSD test, at $5 \%$ probability. To assess the effect of cover crops on soybean stand and yield, data from desiccated cover crops at 30 days before soybean sowing were used. Correlation analysis was performed to quantify the strength of association between herbicide timing, soybean yield, cover crop dry matter, and soybean stand. Regression analysis was applied between herbicide timing and soybean yield.

\section{Results and Discussion}

An interaction between the amount of cover crop on soil surface and herbicide timing was observed, although regression analysis was significant only for U. ruziziensis (Figure 1). In this sense, longer intervals between herbicide application and follow-crop planting significantly reduced the amount of U.ruziziensis biomass on soil surface. However, cover crop biomass, in general, does not affect soybean yield (Table 2 ). When correctly managed, cover crops do not impair soybean emergence and development, even with large biomass. Ricce et al. (2011) observed that cover crops did not affect soybean yield when desiccated at different times before soybean sowing $(30,20,10$, and 0 days).
The amount of straw remaining on soil surface for P. maximum was greater than that for all of the others cover crops (Table 2 ). In addition, dry matter was slightly lower for $P$. maximum in comparison to that obtained by Ferreira et al. (2010), which was $16,584 \mathrm{~kg} \mathrm{ha}^{-1}$. However, with the exception of pearl millet, all of the other cover crops produced considerable biomass, more than $4,000 \mathrm{~kg} \mathrm{ha}^{-1}$ of dry matter. In the NTS, cover crops that produce large amounts of dry matter are desirable for suitable ground cover (Nunes et al., 2006, 2009; Valle \& Pagliarini, 2009; Ferreira et al., 2010).

Parcels under $P$. maximum were significantly different from those under $U$. brizantha in the CTS for soybean plant stand (Table 2). Furthermore, the correlation coefficient between cover crop biomass and soybean plant stand was highly significant (Table 3 ). Monquero et al. (2010) observed lower soybean stand with larger amounts of cover crop biomass, which did not cause reductions in soybean development. Soybean yield under $P$. maximum was similar for almost all treatments, except for fallow plowed, and did not significantly differ from higher yields, even with low soybean plant stand, but differed from parcels under $U$. brizantha plowed (Table 2). According to Peixoto et al. (2000), Scheeren et al. (2010), and Ricce et al. (2011), soybean has greater tolerance to variation in final plant population per area.

The NTS and the CTS with U. brizantha allowed satisfactory yield, which was superior to the national soybean average yield of $2,823 \mathrm{~kg} \mathrm{ha}^{-1}$ in 2010/2011 (Companhia Nacional de Abastecimento, 2011). These findings can be useful for cover crop selection in soil management systems, such as the NTS and the CTS.

Although significant, differences in the amount of cover crop straw they did not cause reduction in soybean yield (Table 2). In addition, correlation analysis showed no significant differences between soybean yield and amount of dry matter (Table 3 ).

Table 1. Soil chemical properties at the experimental area ${ }^{(1)}$.

\begin{tabular}{|c|c|c|c|c|c|c|c|c|c|c|c|}
\hline \multirow{2}{*}{$\begin{array}{l}\text { Depth } \\
(\mathrm{cm})\end{array}$} & \multirow{2}{*}{$\begin{array}{c}\mathrm{pH} \\
\mathrm{H}_{2} \mathrm{O}\end{array}$} & \multirow{2}{*}{\multicolumn{3}{|c|}{$\begin{array}{l}\mathrm{Ca} \\
-----\end{array}$}} & $\mathrm{P}$ & $\mathrm{K}$ & $\mathrm{Cu}$ & $\mathrm{Zn}$ & $\mathrm{Fe}$ & $\mathrm{Mn}$ & \multirow{2}{*}{$\begin{array}{c}\mathrm{MO} \\
\left(\mathrm{g} \mathrm{dm}^{-3}\right)\end{array}$} \\
\hline & & & & & \multicolumn{6}{|c|}{ 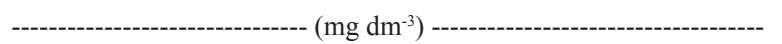 } & \\
\hline $0-5$ & 6.6 & 2.5 & 1.0 & 0.0 & 12.1 & 194.4 & 1.6 & 3.9 & 29.4 & 20.8 & 21.1 \\
\hline $5-10$ & 6.2 & 1.9 & 0.7 & 0.0 & 14.3 & 107.7 & 1.6 & 3.6 & 30.2 & 18.8 & 20.1 \\
\hline $10-20$ & 5.9 & 1.6 & 0.5 & 0.1 & 11.2 & 69.5 & 1.7 & 3.5 & 29.5 & 17.7 & 19.3 \\
\hline
\end{tabular}

${ }^{(1)} \mathrm{P}$ and $\mathrm{K}$ were extracted with Mehlich 1 extracting solution $\left(0.05 \mathrm{M} \mathrm{HC1}\right.$ in $\left.0.0125 \mathrm{M} \mathrm{H}_{2} \mathrm{SO}_{4}\right)$. Phosphorus was determined colorimetrically, and $\mathrm{K}$ by flame photometry. Calcium, $\mathrm{Mg}$, and $\mathrm{Al}$ were extracted with $1.0 \mathrm{M} \mathrm{KC1}$. Aluminum was determined by titration with $\mathrm{NaOH}$ and $\mathrm{Ca}$, and $\mathrm{Mg}$ by titration with EDTA (Claessen, 1997). 
Other authors have reported that a large amount of straw can affect plant growth and yield productivity (Constantin \& Oliveira Junior, 2005; Oliveira Junior et al., 2006; Santos et al., 2007; Monquero et al., 2010). Constantin et al. (2009) found reduction in the initial development and productivity of soybeans emerging

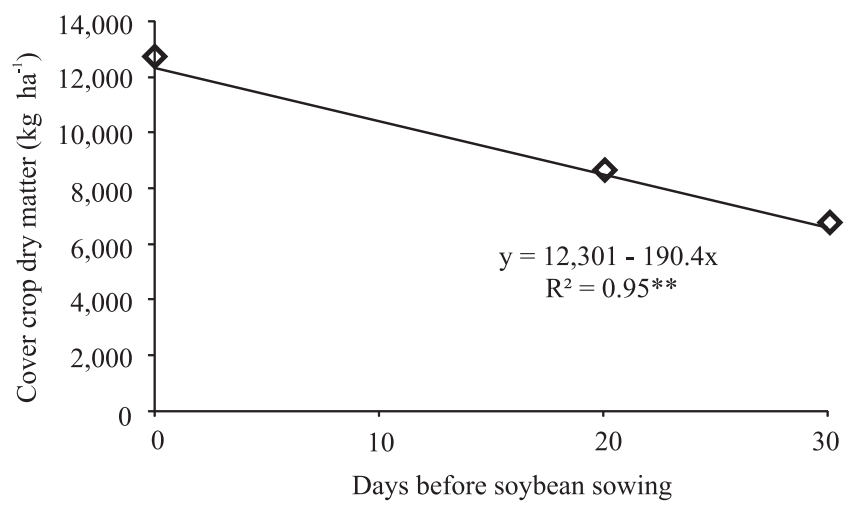

Figure 1. Cover crop dry mater production from Urochloa ruziziensis as a function of pre-emergence herbicide application timing.

Table 2. Cover crop dry matter on soil surface, soybean plant stand measures seven days after seeded, and soybean yield ${ }^{(1)}$.

\begin{tabular}{lccc}
\hline Cover crops & $\begin{array}{c}\text { Dry matter } \\
\left(\mathrm{kg} \mathrm{ha}^{-1}\right)\end{array}$ & $\begin{array}{c}\text { Plant stand } \\
(\mathrm{n}-\text { per } \mathrm{m})\end{array}$ & $\begin{array}{c}\text { Yield } \\
\left(\mathrm{kg} \mathrm{ha}^{-1}\right)\end{array}$ \\
\hline Fallow & $4,487 \mathrm{~cd}$ & $13 \mathrm{ab}$ & $3,658 \mathrm{a}$ \\
Panicum maximum & $13,604 \mathrm{a}$ & $12 \mathrm{~b}$ & $3,746 \mathrm{a}$ \\
Urochloa ruziziensis & $6,207 \mathrm{bc}$ & $14 \mathrm{ab}$ & $3,269 \mathrm{a}$ \\
Urochloa brizantha & $7,614 \mathrm{~b}$ & $15 \mathrm{ab}$ & $3,496 \mathrm{a}$ \\
Pearl millet & $2,793 \mathrm{~d}$ & $16 \mathrm{ab}$ & $3,506 \mathrm{a}$ \\
Fallow plowed & - & $14 \mathrm{ab}$ & $2,616 \mathrm{~b}$ \\
U. brizantha plowed & - & $17 \mathrm{a}$ & $3,607 \mathrm{a}$ \\
\hline Average & 10,029 & 14 & 3,229 \\
Coeficient of variation $(\%)$ & 24.7 & 19.38 & 9.21 \\
p & $<0.0001$ & $<0.0004$ & $<0.0075$ \\
No-tillage & - & $14 \mathrm{a}$ & $3,535 \mathrm{a}$ \\
Tillage & - & $16 \mathrm{a}$ & $3,112 \mathrm{a}$ \\
\hline
\end{tabular}

${ }^{(1)}$ Means followed by equal letters do not differ by the LSD test, at $5 \%$ probability. on soil with large amount of cover crop biomass. This was also observed for parcels under $U$. brizantha, in which plant stands were significantly reduced when herbicide was applied near the soybean sowing date (Figure 2). However, there were no significant interactions between cover crops and herbicide timing for the others treatments.

The correlation of herbicide timing and soybean yield was positive (0.47). There was significant interaction between cover crop $\mathrm{x}$ herbicide timing, and regression analyses were significant only for parcels under $P$. maximum and $U$. brizantha (Figure 3 ). Therefore, for these grasses, increasing the period of time between the application of the herbicide and soybean sowing increases soybean yield. According to Nunes et al. (2009), the best time to apply glyphosate is between 7 and 14 days before soybean sowing, whereas desiccation held over 20 days is detrimental to the crop due to weed reinfestation. Monquero et al. (2010) also reported that straw desiccation more than 20 days before soybean sowing can cause damage in soybean development. However, Oliveira Junior (2006), Santos et al. (2007), and Constantin et al. (2009) recommend that cover crop desiccation should be done more than ten days before sowing to avoid possible cash crop yield reduction caused by the herbicide.

In the $P$. maximum and $U$. brizantha treatments, timing of herbicide application was important for better soybean yield (Figure 3). In both treatments, herbicide application near the sowing date was detrimental to soybean yield. In this sense, Yamada \& Castro (2007) reported that the injury caused by cover crops due to herbicide application near the sowing date of the next summer crop could be aggravated by the higher dry matter yield of cover crops. According to Constantin \& Oliveira Júnior (2005) and Matallo et al. (2009), because of the systemic nature of the effect of glyphosate on cover plants or weeds, it takes a few days to completely kill these plants. Consequently, there is

Table 3. Pearson correlation coefficients and p-value between herbicide timing, soybean yield ( $\left.\mathrm{kg} \mathrm{ha}^{-1}\right)$, cover crop dry matter production (DMP), and soybean plant stand under no-tillage system.

\begin{tabular}{lcccc}
\hline Feature & Herbicide timing & Soybean yield & DMP & Stand \\
\hline Herbicide timing & 1.00 & $0.47(0.0001)$ & $0.44(0.0004)$ & $0.005(0.9696)$ \\
Soybean yield & $0.48(0.0001)^{(1)}$ & 1.00 & $-0.16(0.2158)$ & $-0.13(0.3186)$ \\
DMP & $0.44(0.0004)$ & $-0.16(0.2158)$ & 1.00 & $-0.50(<0.0001)$ \\
Stand & $0.005(0.9696)$ & $-0.13(0.3186)$ & $-0.50(<0.0001)$ & 1.00 \\
\hline
\end{tabular}

${ }^{(1)}$ p-value. Herbicide timings were $0,10,20$, and 30 days before soybean sowing. 
a great expenditure of energy from soybean seedlings to overcome the large amount of cover crop biomass (Constantin et al., 2009).

According to Yamada \& Castro (2007), it is very important to wait from two to three weeks between desiccation and sowing of annual crops to avoid the interference of glyphosate, the allelopathic effect of weeds or shading, and to provide initial rapid and vigorous development of the succeeding crop. Managing the cover crop before sowing of agricultural crops with the use of herbicides brings benefits, such as the reduction of competition for water in early crop development; the promotion of the decomposition of cover crop residues or weeds, which can provide nutrients for the crop; the improvement of the uniformity of planting; the reduction in possible allelopathic effects of cover crops or weeds; and the promotion of increased productivity (Tokura \& Nóbrega, 2006;

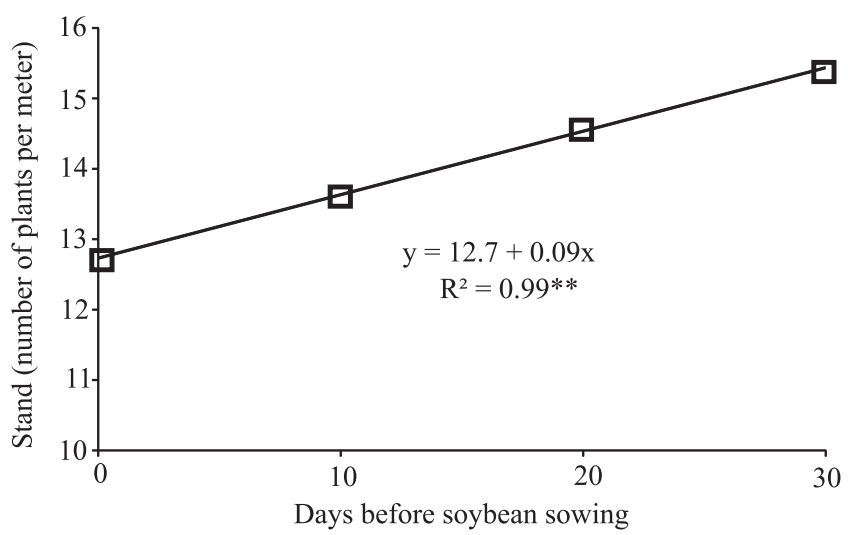

Figure 2. Soybean stand after Urochloa brizantha as a cover crop, as a function of pre-emergence herbicide application timing.

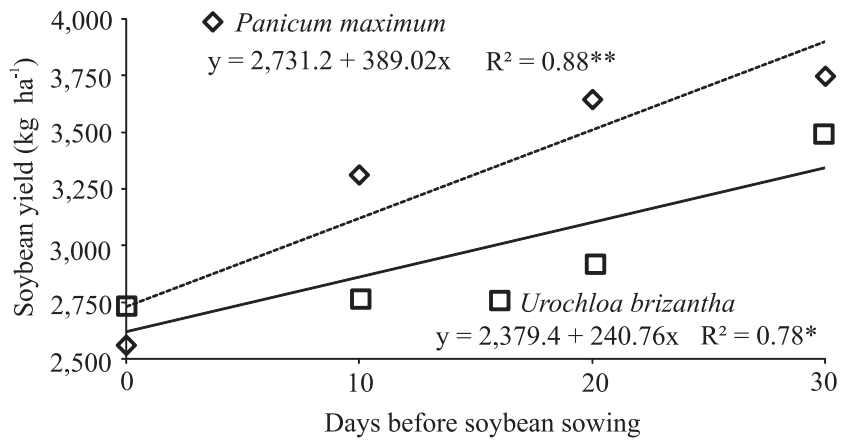

Figure 3. Evaluation of soybean yield under Panicum maximum and Urochloa brizantha cover crops as a function of pre-emergence herbicide application timing.
Borghi \& Crusciol, 2007; Mauli et al., 2011; Yahuza, 2011). U. ruziziensis, pearl millet, and fallow can be desiccated any time before soybean sowing. However, for $P$. maximum and $U$. brizantha, desiccation done near the soybean sowing date causes decreases in crop yield.

\section{Conclusions}

1. The use of different cover crops, such as Urochloa brizantha, U. ruziziensis, Panicum maximum, and pearl millet, under no-tillage system, and U. brizantha in conventional tillage, does not affect soybean yield.

2. Soybean under conventional tillage system after fallow produces the lowest soybean yield.

3. The amount of straw on soil surface does not significantly affect soybean yield.

4. Chemical management of Panicum maximum and $U$. brizantha close to the soybean sowing date reduces soybean yield, but herbicide timing has no effect on soybean yield after fallow, U. ruziziensis, and pearl millet.

\section{Acknowledgements}

To Empresa Brasileira de Pesquisa Agropecuária, for financial support and for scholarship granted; and to Conselho Nacional de Desenvolvimento Científico e Tecnológico, for scholarship granted.

\section{References}

BORGHI, E.; CRUSCIOL, C.A.C. Produtividade de milho, espaçamento e modalidade de consorciação com Brachiaria brizantha em sistema plantio direto. Pesquisa Agropecuária Brasileira, v.42, p.163-171, 2007.

CLAESSEN, M.E.C. (Org.). Manual de métodos de análise de solo. 2.ed. rev. atual. Rio de Janeiro: Embrapa-CNPS, 1997. 212p. (Embrapa-CNPS. Documentos, 1).

COMPANHIA NACIONAL DE ABASTECIMENTO. Acompanhamento da safra brasileira: grãos, oitavo levantamento, safra 2010/2011, maio 2011. Disponível em: <http://www.conab. gov.br/OlalaCMS/uploads/arquivos/11_06_02_10_59_38_ graos_-_boletim_maio-2011..pdf>. Acesso em: 16 jul. 2011.

CONSTANTIN, J.; OLIVEIRA JÚNIOR, R.S. de. Dessecação antecedendo a semeadura direta pode afetar a produtividade. Informe Agronômico, n.109, p.14-15, 2005.

CONSTANTIN, J.; OLIVEIRA JÚNIOR, R.S. de; INOUE, M.H.; CAVALIERI, S.D.; ARANTES, J.G.Z. de. Sistemas de manejo de plantas daninhas no desenvolvimento e na produtividade da soja. Bragantia, v.68, p.125-135, 2009. 
CRUSCIOL, C.A.C.; COTTICA, R.L.; LIMA, E. do V.; ANDREOTTI, M.; MORO, E.; MARCON, E. Persistência de palhada e liberação de nutrientes do nabo forrageiro no plantio direto. Pesquisa Agropecuária Brasileira, v.40, p.161-168, 2005.

DABNEY, S.M.; DELGADO, J.A.; REEVES, D.W. Use of winter cover crops to improve soil and water quality. Communications in Soil Science and Plant Analysis, v.32, p.1221-1250, 2001.

FERREIRA, A.C. de B.; LAMAS, F.M.; CARVALHO, M. da C.S.; SALTON, J.C.; SUASSUNA, N.D. Produção de biomassa por cultivos de cobertura do solo e produtividade do algodoeiro em plantio direto. Pesquisa Agropecuária Brasileira, v.45, p.546-553, 2010.

GALli, A.J.B.; MONTEZUMA, M.C. Alguns aspectos da utilização do herbicida glifosato na agricultura. São Paulo: Monsanto do Brasil, 2005. 66p.

KLUTHCOUSKI, J.; COBUCCI, T.; AIDAR, H.; YOKOYAMA, L.P.; OLIVEIRA, I.P. de; COSTA, J.L. da S.; SILVA, J.G.; VILELA, L.; BARCELlOS A. de O.; MAGNABOSCO, C. de U. Sistema Santa Fé - tecnologia Embrapa: integração lavoura-pecuária pelo consórcio de culturas anuais com forrageiras, em áreas de lavoura, nos sistemas direto e convencional. Santo Antônio de Goiás: Embrapa Arroz e Feijão, 2000. 28p. (Embrapa Arroz e Feijão. Circular técnica, 38).

MATALlO, M.B.; ALMEIDA, S.D.B.; CERDEIRA, A.L.; FRANCO, D.A.; BLANCO, F.M.G.; MENEZES, P.T.C.; LUCHINI, L.C.; MOURA, M.A.; DUKE, S.O. Microwave-assisted solvent extraction and analysis of shikimic acid from plant tissues. Planta Daninha, v.27, p.987-994, 2009.

MAULI, M.M.; NÓBREGA, L.H.P.; ROSA, D.M.; LIMA, G.P. de; RALISH, R. Variation on the amount of winter cover crops residues on weeds incidence and soil seed bank during an agricultural year. Brazilian Archives of Biology and Technology, v.54, p.683-690, 2011.

MONQUERO, P.A.; MILAN, B.; SILVA, P.V.; HIRATA, A.C.S. Intervalo de dessecação de espécies de cobertura do solo antecedendo a semeadura da soja. Planta Daninha, v.28, p.561-573, 2010.

NUNES, A.S.; TIMOSSI, P.C.; PAVANI, M.C.M.D.; ALVES, P.L.C.A. Épocas de manejo químico de Brachiaria decumbens antecedendo o plantio direto de soja. Planta Daninha, v.27, p.297-302, 2009.

NUNES, U.R.; ANDRADE JÚNIOR, V.C.; SILVA, E. de B.; SANTOS, N.F.; COSTA, H.A.O.; FERREIRA, C.A. Produção de palhada de plantas de cobertura e rendimento do feijão em plantio direto. Pesquisa Agropecuária Brasileira, v.41, p.943-948, 2006.

OLIVEIRA JUNIOR, R.S.; CONSTANTIN, J.; COSTA, J.M.; CAVALIERI, S.D.; ARANTES, J.G.Z.; ALONSO, D.G.; ROSO, A.C.; BIFFE, D.F. Interação entre sistemas de manejo e de controle de plantas daninhas em pós-emergência afetando o desenvolvimento e a produtividade da soja. Planta Daninha, v.24, p.721-732, 2006.
OLIVEIRA JUNIOR, R.S.; DVORANEN, E.C.; CONSTANTIN, J.; CAVALIERI, S.D.; FRANCHINI, L.H.M.; RIOS, F.A.; BLAINSKI, E. Influência do glyphosate sobre a nodulação e o crescimento de cultivares de soja resistente ao glyphosate. Planta Daninha, v.26, p.831-843, 2008.

PEIXOTO, C.P.; CÂMARA, G.M. de S.; MARTINS, M.C.; MARCHIORI, L.F.S.; GUERZONI, R.A.; MATTIAZZI, P. Épocas de semeadura e densidade de plantas de soja: I. Componentes da produção e rendimento de grãos. Scientia Agricola, v.57, p.89-96, 2000.

RICCE, W. da S.; ALVES, S.J.; PRETE, C.E.C. Época de dessecação de pastagem de inverno e produtividade de grãos de soja. Pesquisa Agropecuária Brasileira, v.46, p.1220-1225, 2011.

SANTOS, H.G. dos; JACOMINE, P.K.T.; ANJOS, L.H.C. dos; OLIVEIRA, V.A. de; OLIVEIRA, J.B. de; COELHO, M.R.; LUMBRERAS, J.F.; CUNHA, T.J.F. (Ed.). Sistema brasileiro de classificação de solos. 2.ed. Rio de Janeiro: Embrapa Solos, 2006. $306 \mathrm{p}$.

SANTOS, J.B.; SANTOS, E.A.; FIALHO, C.M.T.; SILVA, A.A.; FREITAS, M.A.M. Época de dessecação anterior à semeadura sobre o desenvolvimento da soja resistente ao glyphosate. Planta Daninha, v.25, p.860-875, 2007.

SAS INSTITUTE. Procedure guide for personal computers. Version 5. Cary: SAS Institute, 1999.

SCHEEREN, B.R.; PESKE, S.T.; SCHUCH, L.O.B.; BARROS, A.C.A. Qualidade fisiológica e produtividade de sementes de soja. Revista Brasileira de Sementes, v.32, p.35-41, 2010.

TECNOLOGIAS de produção de soja - região central do Brasil 2007. Londrina: Embrapa Soja, 2006. 225p. (Embrapa Soja. Sistemas de produção, 11).

TOKURA, L.K.; NÓBREGA, L.H.P. Alelopatia de cultivos de cobertura vegetal sobre plantas infestantes. Acta Scientiarum. Agronomy, v.28, p.379-384, 2006.

TORRES, J.L.R.; PEREIRA, M.G.; FABIAN, A.J. Produção de fitomassa por plantas de cobertura e mineralização de seus resíduos em plantio direto. Pesquisa Agropecuária Brasileira, v.43, p.421-428, 2008

VALLE, C.B. do; PAGLIARINI, M.S. Biology, cytogenetics, and breeding of Brachiaria. In: SINGH, R.J. (Ed.). Genetic resources, chromosome engineering, and crop improvement: forage crops. Boca Raton: CRC Press, 2009. v.5, p.103-152.

YAHUZA, I. Review of some methods of calculating intercrop efficiencies with particular reference to the estimates of intercrop benefits in wheat/faba bean system. International Journal of Biosciences, v.1, p.18-30, 2011.

YAMADA, T.; CASTRO, P.R. de C. e. Efeitos do glifosato nas plantas: implicações fisiológicas e agronômicas. Informações Agronômicas, n.119, p.1-32, 2007. 